\title{
Institutional Works in Scholarly Networks: A Rapprochement between Agency and Structure
}

$\underline{\text { Authors }}$

Sang-Bum Park, Korea U. Business School, sb80.park@gmail.com 


\title{
\#14984
}

Institutional Works in Scholarly Networks: A Rapprochement between Agency and Structure

\begin{abstract}
In an academic field, where does brand new idea come from? To understand how noble ideas emerge, this study elucidates how network brokers and high status actors contribute to the creation of knowledge institutions, by paying a specific attention to the interplay between institutional structure and an individual agency in academia. Although numerous scholars have been attempted to relieve the tensions around the agency versus structure debate, accurate explanations of interactive aspects between them are not well documented. To fill this void, this study suggests a conceptual model to explain the complementary and synergetic effects of network structure and agency on the knowledge innovation. In doing so, this study provide an answer to the question of why some actors often fail to obtain significant advantages from a privileged network position while others succeed.
\end{abstract}

Keywords: institutional work, innovation, agency in network 


\section{\#14984}

\section{INTRODUCTION}

Following early work that focused on institutional entrepreneurs (DiMaggio, 1988), institutional scholars have been increasingly examined how institutions and organizational fields change (Dacin, Goodstein, \& Scott, 2002). While contemporary scholars, particularly in the realm of social movement literature (e.g., Hargrave \& Van de Ven, 2006) and technology innovation management literature (e.g., Tushman \& Anderson, 1986) have achieved a great deal in terms of how institutions change, there is still much more to be done about how institutions emerge and what accounts for the differences in the radicalness of such institutional innovation.

If actors are embedded in an institution and subject to regulative, normative and cognitive pressures that structure their behaviors, even confine their interests to institutional norms, how are they able to envision new institutions? Yet, although it is hard to answer directly to this enigmatic question, it is evident that some may have the incentive to create and champion new institutions while others do not. It is also important that institutions do not only constrain, but also are outcomes of agency. To put it differently, organizational actors are not only bound by institutions, but also enact and reconstruct them. In this regard, this study investigates how an institution is innovated, and how such innovation varies across a variety of actors whom each have different interest and capacity. The purpose of this study is to give answers to the following research questions.

First, how do new ideas in academic field come to exist? To understand how novelty emerges and is valued, this study elucidates how network brokers and high status actors contribute to the creation of knowledge institutions, by paying a specific attention to the interplay between an existing institution and an enabling agency in academic fields. With respect to this, it needs to be firstly examined whether and how network brokers and high status actors contribute to the creation of knowledge institutions. 


\section{\#14984}

Second, are scholars who occupy privileged positions in a given network always less constrained by institutional pressures? If so, they may be more likely to initiate new research agenda that can distinguish themselves from others. This is because a unique and distinct identity can be achieved by inventing a theory, or a framework (or at least a measure) that is highly regarded as something new and innovative within or across groups of scientific researchers. However, this study emphasizes that agency has a mediating role in the effects of network structure on knowledge innovations. To recapitulate, this study predicts that the agency will magnify or nullify such advantages of network structure.

\section{INSTITUTIONAL WORKS IN ORGANIZATION STUDIES}

Benefiting from a given network structure is contingent on an individual agency. Nevertheless, in both the previous research in institutional and network theory, this issue has rarely been addressed adequately. Network researchers have traditionally focused on network structure and how individuals are supposed to benefit from an advantage from it. However, it soon became clear that even when an individual were well positioned in the network, some actors benefit more than others. The initial interest of this study arose in part to explain such differences.

Perhaps the most frequent criticism of social network research is that it fails to take into account human agency (e.g., Salancik, 1995; Kilduff \& Brass, 2010: 335). Friedland and Alford's (1991) critique covers much more: It asked why network theory doesn't explain why people are connected, and why power and status do not have universal effects (Thornton, Ocasio, \& Lounsbury, 2012: 3). Networks do not act by themselves. Burt (2012) also stresses that networks are merely the residues of people spending time together while people are the source of action.

As Salancik asserts earlier, why interactions exist cannot be ignored when 


\section{\#14984}

considering the role of networks in a theory of organization (1995: 346). Yet, until very recently, there are only scant mentions of individual differences in network analysis. Instead, network scholars have usually focused on how people differ in their network (Burt, 2012). Nonetheless, network theory offers a fresh perspective for neo-institutionalists interested in understanding how institutions are created, maintained, and disrupted, in several respects (see Lawrence \& Suddaby, 2006). A network analysis can have a special value for organizational scholars with an adequate understanding of the fact that networks are constructed when individuals, whether organizations or humans, interact (Salancik, 1995). Meanwhile, in an adjacent tenet of organization studies, a new emphasis on understanding the role of agency in creating, transforming and maintaining institutions has been emerged under the name of institutional entrepreneurship over the last two decades (Lawrence \& Suddaby, 2006).

Using the view of institutional work, this study attempts to elucidate the interplay between network structure and individual agency, by focusing on the creation and connection of ideas in organization studies. As Tobert and Zucker (1996) early suggest, actor's capacity for strategic action and degree of institutionalization are related concept (Dorado, 2005: 393). As Dorado (2005: 385-386) points out, image of institutional change deriving from the actions of interested actors stems from a long tradition of institutional research (Selznick, 1949; Stinchcombe, 1968). Much of the neo-institutionalist literature on entrepreneurship examines the attributes of individuals, the networks of affiliations in which those individuals are situated, and the resources they assemble (Hwang \& Powell, 2005: 179).

On the one hand, because the a recent stream of neo-institutionalism bring back into account adaptive behavior motivated by human agency and interests (DiMaggio, 1988), neoinstitutional theories offer a promising means of capturing the dynamics (Fligstein \& Freeland, 1995) and complexity (Baum \& Singh, 1994) of the interaction between institutions and organizations (Carney \& Gedajlovic, 2002: 2). This agentic turn in institutional theory 


\section{\#14984}

has marked a shift in attention from the isomorphic forces that stabilize organizational fields toward consideration of the dynamic processes by which fields form and transform (Dacin, Goodstein, \& Scott, 2002). However, despite the agentic turn, there has been a relative lack of research concerning how individual make choices in response to institutional constraints. Network analysis in organization theory, on the other hand, has the merit to evaluate how extant networks affect either the flow of information and resources to individual actorsorganizations or individuals — or how individual actors gain prestige or influence through their positions in networks (Salancik, 1995: 346).

This study lends more weight to the complementary roles of social network and institutional theory than each independent theoretical merit. A more nuanced explanatory power derives from recognizing such interdependent roles of the two theories in a model of institutional change (Battilana \& Casciaro, 2012). Unlike prior studies that have oversimplified the interactions between the agency and structure, this study provide a set of propositions that lies behind the orthogonal effects of network structure and agency on the institutional constraints.

\section{INTERPLAY BETWEEN NETWORK STRUCTURE AND AGENCY}

While institutions constrain action they also provide sources of agency and change (Thornton \& Ocasio, 2008). Decisions and outcomes are a result of the interplay between individual agency and institutional structure (Jackall, 1988; Friedland \& Alford, 1991; Thornton \& Ocasio, 1999). Giddens (1984) also points out that individual actors are simultaneously constrained and enabled by existing social structures (Thornton \& Ocasio, 2008: 103). Institutional logics are "socially constructed, historical patterns of material practices, assumptions, values, beliefs and rules" (Thornton \& Ocasio, 1999: 804). Logics establish "the rules of the game" and thereby shape beliefs and behavior, even as actors can 


\section{\#14984}

inform and influence these rules. An institutional logic provides a coherent set of guideline and principles for a particular realm of social life (Besharov \& Smith, forthcoming).

It has long been commented that there is a danger in network analysis of not seeing the trees for the forest (Salancik, 1995: 346). Until recent years, however, there has been a relative lack of research explain how an individual make choices concerning the social networks that facilitate and constrain their actions (Kilduff \& Brass, 2010). Compared to the structural hole versus closure debate (e.g., Ahuja, 2000) or the structure versus actor characteristics debate (e.g., Burt, 2012), the agency versus structure debate has yet to demonstrate a driving force in developing social network research (Kilduff \& Brass, 2010: 336). Another criticism on the past social network research stems from its neglect of the content of network. That means little effort has been made to understand the content of ties, and even less effort to examine what kinds of ties matter for what outcomes (Haveman, 2000).

To tackle this issue, this study investigates the way in which actors bring about institutional innovation more or less radically by taking advantages from privileged positions (e.g., broker, high status) on a given network. However, it cannot be ignored that actors have different capabilities and the relations have different meanings (Borgatti \& Foster, 2003: 1001). Further, the paper addresses the question of how much control actors have over the networks that constrain and enable their behaviors.

\section{Network Positions and Institutional Conformity}

There are two competing assumptions around scholarly activities (e.g., publication). While many people regard scientific ideas as the product of scholar's pure reasoning, some people doubt that this is a naïve belief rather than a fact. As Camic and Gross (2004) point out, scholars' reasoning is never context-free but embedded in the intellectual tradition in the research community in which ideas are developed. The underlying assumption of this study is 


\section{\#14984}

that scholars become embedded in their community's institutional norms during their academic socialization (Sieweke, 2013) and professionalization (DiMaggio \& Powell, 1983).

In some sense, academia is one of the most institutionalized fields in all area of human culture. Despite its relative lack of coercive influences, there is little doubt that academia are strongly confined to normative pressure. Moreover, scholars are also susceptible to mimetic forces (e.g., fashionable terms). Like a management fashion (Abrahamson, 1996), an academic fashion also can become an institutional force, and scholars are often subjected to the whims of fashion (Perkmann \& Spicer, 2008: 813). As Simmel (1957/1905: 543) points, a fashion are what usually happens and what one would expect, science is not an exception. Imitating a good example (e.g., using a concept of highly cited articles) - if there is nothing wrong with plagiarism - is a common and safe way to satisfy the demand for social adaptation in academic fields.

For these reasons, professionals (e.g., scholars) and their associations (e.g., research communities) are often work as agents of reproduction rather than of change (Greenwood, Suddaby, \& Hinings, 2002: 73). Theories and terminologies a scholar frequently uses signify his academic identity. Because categorization defines individual identities and what an individual scholars is expected to be by his audiences (e.g. colleagues), clear identity confers various advantages, whereas ambiguous one imposes sanctions (see Zuckerman, 1999). For example, in the film industry, young actors whose careers have spanned multiple genres have a harder time getting a job (Zuckerman, Kim, Ukanwa, \& von Rittmann, 2003). Therefore, based on the literature review in this section, the proposition is developed as follows:

Proposition 1: The greater the institutional conformity pressure in certain network position, the more likely the knowledge producers will maintain and reinforce existing ideas in their fields. 


\section{\#14984}

\section{Agency and Knowledge Innovation}

Agency became more crucial for understanding not only institutions but also networks. This is because actors engage in institutions differently with multiple levels of their agency. Agency is a multidimensional concept (Emirbayer \& Mische, 1998). It is sometimes associated with terms such as motivation, will, intention, interest, autonomy, and freedom, and is often referred to as actors' ability to make choices against the institutional constraints (Battilana \& D'Aunno, 2009). This study focuses on actor's interest and capacity on behalf of these various conceptual components.

Agency plays a role in institutional creation, maintenance, and change. The effect of institution on action is neither denied nor ignored, but the focus of this study is on how agency moderates this effect. Some actors leverage resources to create new institutions or to transform existing ones (Maguire et al., 2004). In other words, some actors are better at coping with institutional constraints and realizing their self-interests (DiMaggio, 1988; Eisenstadt, 1964, 1968; Fligstein, 1997). High level of institutionalization that imposes high conformity pressure can be relaxed by high level of agency. Level of agency varies according to an actor's interest and capacity. These arguments suggest the following proposition.

Proposition 2: The higher the agency, the more likely the knowledge producers will engage in institutional work that creates new scientific idea or disrupts the existing one even if the pressure to conform is high.

Structural holes. In academic community of management and organization studies (MOS), some scholars are willing to span their network across their clique while others only interact with colleagues, cling to cohesive relationships within their clique. As Vogel (2012: 1015) quotes, MOS is virtually inhabited by individuals who are gathered into guilds and live in 


\section{\#14984}

groups of small cottages (Battilana, Anteby, \& Sengul, 2010: 695), and these guilds strive to establish their own chapel and to convince people that it is better than the neighboring chapel (Courpasson, Arellano-Gault, Brown, \& Lounsbury, 2008: 1387). Within a clique of such cottages and chapels, it is rare to observe a cross-cutting activity or a penetration that spans networks across profession cliques in scientific and scholarly networks. Even though that, some scholars attempted to bridge across different cliques.

For example, a resource-based view (RBV) in strategic management and institutional theory in organization theory developed independently without cross-fertilization until mid1990s when Christine Oliver (1997) took her seminar research to combine institutional theory and RBV. She roles as a network broker who spans structural holes, acting as a go-between for those not directly connected. An institutional-based view of international business that was firstly proposed by Mike Peng (2002) and popularized by same scholar (Peng, 2006) is an example of institutional innovation that was possible due to her brokerage.

In this sense, it is important to note that knowledge innovation is not only originated from knowledge properties (i.e., literally new idea), but also derived from relational properties of knowledge. That is, even though an idea has been exploited and hackneyed in a certain domain of academic area, it can be perceived and even welcomed as a new and an unprecedented idea in elsewhere (Burt, 2004). As Van de Ven, Polley, Garud and Venkataraman point out that as long as the idea is perceived as new to the people involved, it is an innovative idea, even though it may appear to others to be an imitation of something that exists elsewhere (1999: 9). Incommensurability of agency and structure also can be relieved through such cognitive viewpoints (e.g., Kilduff \& Krackhardt, 1994). It does matter how an actor perceives the institutional constraint instead of its actual degree.

Structural holes endow opportunities to create noble ideas. Scholar who has relations that span structural holes between cliques is less constrained by institutional fetters. Weak ties 


\section{\#14984}

that span structural holes are certainly more preferable than strong ties to an actor who secures nonredundant information (Granovetter, 1973; Burt, 1992). By the same token, the value of social capital is magnified in structural holes (Burt, 1997). Given the distinction between structural and relational embeddedness (Granovetter, 1992; Gulati \& Gargulio, 1999; McEvily \& Reagans, 2003), this study places emphasis on a broker's ego networks. Institutional work represents the broad category of purposive action aimed at creating, maintaining and disrupting institutions (Lawrence \& Suddaby, 2006; Lawrence et al., 2009). This study particularly focuses on institutional works in terms of knowledge innovation, which is the product of people to build and change institutions. To sum, from the literature emphasizing the effect of brokerage in generating and transferring knowledge in scientific and scholarly networks or S\&SNs (White, 2011), following proposition can be presented.

Proposition 3: Ceteris paribus, a network broker whose ego network consists of disconnected alters is more likely to lead knowledge innovation rather than conform (acquiesce, maintain, reinforce) to existing idea.

Status. Actors who engage in competition often hover over the cusp between pressures to conform and to differentiate. While, firms demonstrate their legitimacy by conforming and similar to others, they should differentiate themselves from others to stand out. In short, to be different or to be the same, it's a question (Deephouse, 1999). Accordingly, conformity pressures vary depending upon which stage an actor is situated (Zuckerman, 1999). That is, an actor is likely to attempt to be similar to other promising candidates to win legitimacy in the first stage where she does not yet fit existing category-i.e., audience's minimal criteria, whereas she is likely to differentiate herself from others to be more attractive in the second stage where she plays as a legitimate candidate. 


\section{\#14984}

Citing Garud et al. (2007: 961), Höllerer points out that core actors in a filed 'may have the power to force change but often lack the motivation; while peripheral players may have the incentive to champion new practices, but often lack the power to change institutions (2013: 574). Key mechanisms which institutional logics shape individual cognition are social classification and categorization (DiMaggio, 1997). Classification and categorization of organizational categories are determined by social institutions (Douglas, 1986; Searle, 1995; Thornton \& Ocasio, 2008: 112-113).

In addition to its categorical nature, conformity pressure is high at the middle and low at either end of a status order (Phillips \& Zuckerman, 2001). It means that freedom from such pressure can be maximized when an actor is positioned at the top or bottom of a hierarchy. An inverted U-shaped relationship is expected between status and knowledge innovations. Therefore, another proposition is developed as follows:

Proposition 4: Ceteris paribus, there exists a curvilinear relationship between status of knowledge producer and his tendency to engage in institutional work that creates new idea or disrupt old one.

Agency. The effects of network structure on knowledge innovation can be expedited or deterred according to agency. This is because, on the one hand, agency (e.g., freedom to act willfully) can relieve disadvantages of network constraints or middle status conformity, but on the other hand, it can boost advantages of network brokerage or high status freedom.

Proposition 5: Ceteris paribus, the effect of network position (brokerage, high status) is more positively related to knowledge producer's creation of scientific innovative idea when knowledge producers has high agency than when they has low agency. 


\section{\#14984}

\section{DISCUSSIONS}

\section{Conclusion}

Conventional wisdom advises us to refrain from talking with strangers. It is a natural tendency of ordinary people to spend most of their time on working with whom they are familiar. "Don’t talk to strangers" says, "Stay from anyone who's not familiar to you" (Bezaitis, 2013). Undeniably, scholars in the field of academia also abide in this special kind of social norm. A close and cohesive relationship within familiar colleagues may bring about a lot of benefits. That is, such closure can help transfer credible knowledge information and also can ease collaboration.

Every community, as it gains strength and matures, runs the risk of becoming too much of a closed system (Battilana et al., 2010: 710). However, brand new ideas might become fairly scarce when a clique is stagnant. As the Medici chapel in Renaissance Florence shows, people can create value by integrating separate sectors that had previously been rarely connected (Padgett \& Ansell, 1993). Nonetheless, it does not necessarily mean that anyone who is positioned well in network structure can lead such an innovation. Neither agency nor structure does work alone. This is why we should pay serious attention to interplay between them.

As Burt (2004) nicely capture, a scientific idea is socially constructed as all kinds of idea. We, students and scholars, are socialized differently through multiple academic disciplines, and thereby we become differently institutionalized. Organization and management theory (OMT), neighboring field to both strategic management and organizational sociology, is a multidisciplinary multiscience (Baum \& Dobbin, 2000). Despite a lot of similarities and associations, we often find that our routine practices and languages are not like theirs. The more we became familiar with our words, the more we became hard of hearing someone else's. 


\section{\#14984}

Let me give an example of my own personal experience. When I first heard, resource-based view or RBV, which is one of the dominant perspectives in strategic management, reminded me of resource dependency theory or RDT that is well known to those who are majored in sociology like me. Until I could discern the difference between the two, I was confused that they are almost identical. It is not only me who experiences this sort of thing. A few months ago, I heard from my advisor that he met a female scholar who majored in sociology and is currently working as a professor in a U.S. business school, and she told him that she didn't know Jay B. Barney_one of the most prominent scholar in the field of strategic management - until she met Professor Barney at a conference and she had never even heard of his name before. She also thought of RBV as a synonym of RDT at the first time she listened to it. This is evidence, I believe, showing academic fields are highly subdivided and research communities are differently institutionalized. This exemplifies, I further think, the idea that we barricade ourselves from against strangeness.

However, stagnant water is bounded to rot. No matter how sophisticated we are with our languages and ways of thinking, no matter how some of us have their own lives and have lived them self sufficiently, we will end up being prisoners of the iron cage of our institutions unless the institutions in which we are enmeshed are rejuvenated by succeeding generations of new ideas. For these reasons, I began to explore how new scientific idea create new institutions, and where such institutional innovations come from with a special interest in the interplay between agency and structure.

\section{Implications}

This study can offer some implications to the field of organization theory as follows. First, the key contribution of this study is to provide a nuanced complementary view, which combines agency into institutional and social network analysis. While the agency-structure 


\section{$\# 14984$}

debate - often referred to as the paradox of embedded-agency within institutional theory (e.g., DiMaggio and Powell, 1991) — is broadly recognized as central concern among institutional and institutional entrepreneurial research, this paradox still remains unresolved ( $\mathrm{Ng}, 2013)$. Yet, although a considerable amount of effort has been put to ease the tension between agency and structure, they have been relatively silent about complementary and interactive aspects between agency and structure. While this complementarity issue still remains almost as theoretically barren, this study attempts to puzzle out this enigma by using the framework of institutional work, which was provided by the recent literature in institutional entrepreneurship. This study demonstrates how network structure and agency are complementary to each other and would make different results than what they may cause independently. In this way we can get a better understanding of how people generate new idea against the institutional challenges.

Second, this study offers an explanation about micro-foundations of macro phenomena. Although previous studies on knowledge and institutions focus either on the micro - organizational or individual levels — or the macro — societal or field levels, the meso - connections between micro and macro level— has been sparsely studied. This micromacro divide in institutional research is partially due to the fact that each level studies differ in terms of their underlying paradigmatic stand (Zilber, Lounsbury \& Meyer, 2013). While it is undeniably true, it is also true that there have been growing concerns about the necessity and importance of bridging the two. In this regard, this study contributes to answering a question of how to explore and explain macro-level processes without losing sight of their micro-level foundations.

Third, this study contributes to the literature of institutional entrepreneurship. The debate about the role of agency versus structure in social life has touched all areas of the social sciences (Archer, 1982). It corresponds to the agency versus structure debate in the 


\section{\#14984}

framework of institutional theory (Battilana and D'Aunno, 2009). Perhaps the most central quarrel dividing institutionalists is the structure versus agency debate (Heugens \& Lander, 2009; Hirsch \& Lounsbury, 1997). In this regard, this study attempts to contribute more sophisticated and adequate approach for both institutional and network theory. This unique model is also expected to help us better understand the dynamic effects of conformity on institutional innovation.

\section{Limitations and Future Research Directions}

As Thomas A. Edison said, there is always a better way. For this challenging study to be complete, much more is needed than what is done here. Despite these contributions, this study has some limitations.

First, other scenarios can be possible. For instance, other structural properties (e.g., range) also may have impacts on knowledge innovation. The closure may also play a pivotal role in institutional change.

Second, future research should consider the previous research that dealt with the role of agency in the institutional changes. For example, the concept of internal dynamics can be applied to the topic of institutional creation. The internal dynamics are twofold: precipitating (i.e., interests and value commitments) and enabling (i.e., capacity) (Greenwood \& Hinings, 1996).

Third, future research can expand the scope of this topic by paying special attention to survival of academic subfield. Despite the growing consensus that networks matter, the specific effects of network structure on organizational performance remain inconclusive (Ahuja, 2000: 425). Goals of scholarly groups in academic fields are often subverted, and moreover, the continuation and survival sometimes become the primary concern to given members. In this regard, some questions deserve to be studied are: Why couldn't 


\section{\#14984}

Scandinavian institutionalism flourish but fade away? Did this kind of a distinctive and identifiable variant of institutionalism fail to get an attention simply because of its peripheral nature on the geographical map of academia?

Scandinavian institutionalism highlights organizational variation and distinctiveness rather than isomorphism and standardization (Boxenbaum and Pedersen, 2009). Although it stayed ahead of the other institutional scholars in Western Europe or the United States, it failed to thrive. In contrast, neo-institutional theory (e.g., DiMaggio \& Powell, 1983;

DiMaggio, 1988; Meyer \& Rowan, 1977; Meyer \& Scott, 1983; Scott \& Meyer, 1994; Zucker, 1977; Tolbert \& Zucker, 1983) has emerged as one of the most influential ideas in organizational studies, penetrating into other realms of MOS. Its penetration into the field of international business and strategy management literature is a more recent phenomenon since the 1990s (Oliver, 1997; Peng \& Heath, 1996).

Last but not least, future research will also benefited from institutional logic perspective (Thornton, Ocasio, \& Lounsbury, 2012) and the sociology of entrepreneurship (Thornton, 1999) in terms of institutional innovation and knowledge creation. 


\section{\#14984}

\section{REFERENCES}

Ahuja, G. 2000. Collaboration networks, structural holes, and innovation: A longitudinal study. Administrative Science Quarterly, 45(3): 425-455.

Battilana, J. 2006. Agency and institutions: The enabling role of individuals' social position. Organization, 13(5): 653-676.

Battilana, J., Anteby, M., \& Sengul, M. 2010. The circulation of ideas across academic communities: When locals re-import exported ideas. Organization Studies, 31(6): 695-713.

Battilana, J., \& Casciaro, T. 2012. Change agents, networks, and institutions: A contingency theory of organizational change. Academy of Management Journal, 55(2): 381-398.

Battilana, J., \& D’Aunno, T. 2009. Institutional work and the paradox of embedded agency. In T. B. Lawrence, R. Suddaby, \& B. Leca (Eds.), Institutional work: Actors and agency in institutional studies of organizations: $31-58$. Cambridge, UK: Cambridge University Press.

Battilana, J., Leca, B., \& Boxenbaum, E. 2009. How actors change institutions: Towards a theory of institutional entrepreneurship. Academy of Management Annals, 3(1): 65107.

Besharov, M. L., \& Smith, W. K. forthcoming. Multiple logics in organizations: Explaining their varied nature and implications. American Review of Management.

Borgatti, S. P., \& Foster, P. C. 2003. The network paradigm in organizational research: A review and typology. Journal of Management, 29(6): 991-1013. 


\section{\#14984}

Bothner, M. S., Kim, Y., \& Smith, E. B. 2012. How does status affect performance? Status as an asset vs. status as a liability in the PGA and NASCAR. Organization Science, 23(2): 416-433.

Burt, R. S. 1987. Social contagion and innovation: Cohesion versus structural equivalence. American Journal of Sociology, 92(6): 1287-1335.

Burt, R. S. 2012. Network-related personality and the agency question: Multirole evidence from a virtual world. American Journal of Sociology, 118(3): 543-591.

Dacin, M. T., Goodstein, J., \& Scott, W. R. 2002. Institutional theory and institutional change: Introduction to the special research forum. Academy of Management Journal, 45(1): 43-56.

Davis, C. H., \& Cronin, B. 1993. Acknowledgments and intellectual indebtedness: A bibliometric conjecture. Journal of the American Society for Information Science, 44(10): 590-592.

Deephouse, D. L. 1999. To be different, or to be the same? It's a question (and theory) of strategic balance. Strategic Management Journal, 20(2): 147-166.

Deephouse, D. L. 2000. Media reputation as a strategic resource: An integration of mass communication and resource-based theories. Journal of Management, 26(6): 10911112.

DiMaggio, P. J. 1988. Interest and agency in institutional theory. In L. G. Zucker (Ed.), Institutional patterns and organizations: 3-22. Cambridge, MA: Ballinger.

DiMaggio, P. J. 1997. Culture and cognition. Annual Review of Sociology, 23: 263-287. 


\section{\#14984}

DiMaggio, P. J., \& Powell, W. W. 1983. The iron cage revisited: Institutional isomorphism and collective rationality in organizational fields. American Sociological Review, 48(2): $147-160$.

Dobrev, S. D., \& Barnett, W. P. 2005. Organizational roles and transition to entrepreneurship. Academy of Management Journal, 48(3): 433-449.

Dorado, S. 2005. Institutional entrepreneurship, partaking, and convening. Organization Studies, 26(3): 385-414.

Emirbayer, M., \& Mische, A. 1998. What is agency? American Journal of Sociology, 103(4): 962-1023.

Etemad, H., \& Lee, Y. 2003. The knowledge network of international entrepreneurship: Theory and evidence. Small Business Economics, 20(1): 5-23.

Gonzalez-Brambila, C. N., Veloso, F. M., \& Krackhardt, D. 2013. The impact of network embeddedness on research output. Research Policy, 42(9): 1555-1567.

Granovetter, M. 1992. Problems of explanation in economic sociology. In N. Nohria \& R. G. Eccles (Eds.), Networks and organizations: 25-56. Boston, MA: Harvard Business School.

Greenwood, R., \& Hinings, C. R. 1996. Understanding radical organizational change: Bringing together the old and the new institutionalism. Academy of Management Review, 21(4): 1022. 


\section{\#14984}

Greenwood, R., Suddaby, R., \& Hinings, C. R. 2002. Theorizing change: The role of professional associations in the transformation of institutionalized fields. The Academy of Management Journal, 45(1): 58-80.

Hargrave, T. J., \& Van de Ven, A. H. 2006. A collective action model of institutional innovation. Academy of Management Review, 31(4): 864-888.

Haveman, H. A. 2000. The future of organizational sociology: Forging ties among paradigms. Contemporary Sociology, 29(3): 476-486.

Heugens, P. P. M. A. R., \& Lander, M. W. 2009. Structure! agency! (and other quarrels): A meta-analysis of institutional theories of organization. Academy of Management Journal, 52(1): 61-85.

Hirsch, P. M., \& Lounsbury, M. 1997. Ending the family quarrel: Toward a reconciliation of "old" and "new" institutionalisms. American Behavioral Scientist, 40(4): 406-418.

Höllerer, M. A. 2013. From taken-for-granted to explicit commitment: The rise of CSR in a corporatist country. Journal of Management Studies, 50(4): 573-606.

Jay, J. 2013. Navigating paradox as a mechanism of change and innovation in hybrid organizations. Academy of Management Journal, 56(1): 137-159.

Kilduff, M., \& Brass, D. J. 2010. Organizational social network research: Core ideas and key debates. Academy of Management Annals, 4(1): 317-357.

Kilduff, M., \& Krackhardt, D. 1994. Bringing the individual back in: A structural analysis of the internal market for reputation in organizations. Academy of Management Journal, 37(1): 87-108. 


\section{\#14984}

Kim, Y. 2008. An examination of status dynamics in the U.S. venture capital industry. The University of Chicago, Illinois, United States.

Lawrence, T. B., \& Phillips, N. 2004. From moby dick to free willy: Macro-cultural discourse and institutional entrepreneurship in emerging institutional fields. Organization, 11(5): 689-711.

Lawrence, T. B., \& Suddaby, R. 2006. Institutions and institutional work. In S. R. Clegg, C. Hardy, T. B. Lawrence \& W. R. Nord (Eds.), Handbook of organization studies: 215-254. London, Sage.

Lawrence, T. B., Suddaby, R., \& Leca, B. 2009. Introduction: Theorizing and studying institutional work. In T. B. Lawrence, R. Suddaby, \& B. Leca (Eds.), Institutional work: Actors and agency in institutional studies of organizations: 1-27. Cambridge, UK: Cambridge University Press.

Lepak, D. P., Smith, K. G., \& Taylor, M. S. 2007. Value creation and value capture: A multilevel perspective. Academy of Management Review, 32(1): 180-194.

Li, E. Y., Liao, C. H., \& Yen, H. R. 2013. Co-authorship networks and research impact: A social capital perspective. Research Policy, 42(9): 1515-1530.

Lounsbury, M., \& Crumley, E. T. 2007. New practice creation: An institutional perspective on innovation. Organization Studies, 28(7): 993-1012.

Mannheim, K. 1936. Ideology and utopia. New York: Harcourt, Brace \& Company.

Meyer, J. W., \& Rowan, B. 1977. Institutionalized organizations: Formal structure as myth and ceremony. American Journal of Sociology, 83(2): 340-363. 


\section{\#14984}

Meyer, J. W., \& Scott, W. R. 1983. Organizational environments: Ritual and rationality. Beverly Hills, CA: Sage.

North, D. C. 1990. Institutions, institutional change, and economic performance. Cambridge ; New York: Harvard University Press.

Oliver, C. 1997. Sustainable competitive advantage: Combining institutional and resourcebased views. Strategic Management Journal, 18(9): 697-713.

Padgett, J. F., \& Ansell, C. K. 1993. Robust action and the rise of the medici, 1400-1434. American Journal of Sociology, 98(6): 1259-1319.

Peng, M. W., \& Heath, P. S. 1996. The growth of the firm in planned economies in transition: Institutions, organizations, and strategic choice. Academy of Management Review, 21(2): 492-528.

Perkmann, M., \& Spicer, A. 2008. How are management fashions institutionalized? The role of institutional work. Human Relations, 61(6): 811-844.

Phillips, D. J., \& Zuckerman, E. W. 2001. Middle-status conformity: Theoretical restatement and empirical demonstration in two markets. American Journal of Sociology, 107(2): $379-429$.

Pratt, M. G., \& Rafaeli, A. 1997. Organizational dress as a symbol of multilayered social identities. Academy of Management Journal, 40(4): 862-898.

Salancik, G. R. 1995. WANTED: A good network theory of organization. Administrative Science Quarterly, 40(2): 345-349. 
\#14984

Scott, W. R., \& Meyer, J. W. 1994. Institutional environments and organizations: Structural complexity and individualism. Thousand Oaks, CA: Sage.

Sieweke, J. 2013. The influence of intellectual traditions on the diffusion of scientific ideas. Paper presented at the annual meeting of the Academy of Management, Orlando.

Simmel, G. 1957/1905. Fashion. American Journal of Sociology, 62, 541-558.

Suddaby, R., Elsbach, K. D., Greenwood, R., Meyer, J. W., \& Zilber, T. B. 2010. Organizations and their institutional environments — bringing meaning, values, and culture back in: Introduction to the special research forum. Academy of Management Journal, 53(6): 1234-1240.

Thornton, P. H. 1999. The sociology of entrepreneurship. Annual Review of Sociology, 25: 19-46.

Thornton, P. H., \& Ocasio, W. 2008. Institutional logics. In R. Greenwood, C. Oliver, R. Suddaby, \& K. Sahlin-Andersson (Eds.), The SAGE handbook of organizational institutionalism: 99-129. CA: Sage: Thousand Oaks.

Thornton, P. H., Ocasio, W., \& Lounsbury, M. 2012. Introduction to the institutional logics perspective. In P. H. Thornton, W. Ocasio, \& M. Lounsbury (Eds.), The institutional logics perspective: A new approach to culture, structure, and process: 1-19. Oxford, England: Oxford University Press.

Thornton, P. H., \& Ocasio, W. 2008. Institutional logics. In R. Greenwood, C. Oliver, R. Suddaby, \& K. Sahlin-Andersson (Eds.), The Sage handbook of organizational institutionalism: 99-129. Thousand Oaks, CA: Sage. 
Tolbert, P. S., \& Zucker, L. G. 1983. Institutional sources of change in the formal structure of organizations: The diffusion of civil service reform, 1880-1935. Administrative Science Quarterly, 28(1): 22-39.

Tobert, P. S., \& Zucker, L. G. 1996. The institutionalization of institutional theory. In S. R. Clegg, C. Hardy \& W. R. Nord (Eds.), Handbook of organization studies: 175-190. London, Sage.

Tushman, M. L., \& Anderson, P. 1986. Technological discontinuities and organizational environments. Administrative Science Quarterly, 31(3): 439-465.

Van de Ven, A. H., Polley, D., Garud, R., \& Venkataraman, S. 1999. The innovation journey. Oxford: Oxford University Press.

Vogel, R. 2012. The visible colleges of management and organization studies: A bibliometric analysis of academic journals. Organization Studies, 33(8): 1015-1043.

White, H. D. 2011. Scientific and scholarly networks. In J. Scott \& P. J. Carrington (Eds.), The SAGE handbook of social network analysis: 271-285. London: Sage.

Wijk, J. v., Stam, W., Elfring, T., Zietsma, C., \& Hond, F. d. 2013. Activists and incumbents structuring change: The interplay of agency, culture, and networks in field evolution. Academy of Management Journal, 56(2): 358-386.

Zucker, L. G. 1977. The role of institutionalization in cultural persistence. American Sociological Review, 42(5): 726-743.

Zuckerman, E. W. 1999. The categorical imperative: Securities analysts and the illegitimacy discount. American Journal of Sociology, 104(5): 1398-1438. 


\section{\#14984}

Zuckerman, E. W., Kim, T., Ukanwa, K., \& von Rittmann, J. 2003. Robust identities or nonentities? Typecasting in the feature-film labor market. American Journal of Sociology, 108(5): 1018-1074. 